\title{
Actual Evapotranspiration Estimation Using a Penman-Monteith Model
}

\author{
N. C. Sanjay Shekar and Lakshman Nandagiri
}

\begin{abstract}
The present study was taken up to evaluate the applicability of the Penman-Monteith (PM) equation with a simple surface conductance model to estimate latent heat flux $(\lambda E T)$ in a humid tropical region. The model has been proposed by previous researchers. The selected study area is the Mae-Klong Watershed Research Station, Kanchanaburi, Thailand where latent heat flux measurements were available from a flux tower. The PM model was applied using ground-based climate data and Moderate Resolution Imaging Spectroradiometer (MODIS) remote sensing satellite data products corresponding to the study area. Comparison of estimated and measured fluxes at the tower on eight days in 2004 yielded root mean square error (RMSE) of $16.10 \mathrm{~W} / \mathrm{m}^{2}$. The satellite-based PM algorithm tested in this study appears to provide reasonably accurate results and may be used to map latent heat flux and actual evapotranspiration at catchment/regional-scales in a cost effective and convenient manner.
\end{abstract}

Keywords - Evapotranspiration, Latent heat flux, Flux tower, Penman-Monteith equation, MODIS, Sub-humid tropical region

\section{INTRODUCTION}

Actual Evapotranspiration (AET) is a major component of the hydrological cycle and accounts for 60 percent of the annual water balance in semi-arid climates. Accurate estimation of AET is crucial for agricultural water management, hydrological modeling and environmental assessments. Many efforts have been made in the past decades to estimate AET at various spatial and temporal scales. While reasonably accurate methods to estimate point to field scale AET from agricultural crops are available, methods to estimate catchment to regional scale AET are lacking.

Therefore, efforts are being made to use satellite remote sensing imagery to map AET at regional scales in a convenient and economically feasible manner [1], [4]. Remote sensing data products have been using widely to produce time series information on climatic modeling [3], [9], [15].These methods use information on biophysical properties of land surfaces data provided by satellite imagery such as MODIS [11] to estimate AET from surface energy balance or physically-based equations such as the Penman-Monteith (PM). Methods based

Manuscript received January. 9, 2016

N. C. Sanjay Shekar, Ph.D Scholar, Department of Applied Mechanics \& Hydraulics, National Institute of Technology Karnataka, Surathkal, Mangalore 575025, India.

Lakshman Nandagiri, Professor, Department of Applied Mechanics \& Hydraulics, National Institute of Technology Karnataka, Surathkal, Mangalore 575025, India. on the energy balance approach are usually more complex and also data intensive, rendering their applicability in data-short situations impractical. The PM equation is a biophysically sound and robust framework for estimating daily ET at regional to global scales using remotely sensed data [8], [16]. However, one of the largest sources of uncertainty in the Penman-Monteith equation is the parameterization of the surface conductance. Therefore, a simple biophysical model for estimation of surface conductance estimation was introduced by Leung et al. [11]. This model uses remotely sensed data on Leaf area index (LAI) data as input to the PM equation to estimate daily AET at kilometre spatial resolution. Validation with flux tower data proved that the method was reasonably accurate [11].

However, in developing countries located in the humid tropics, due to scarcity of ground based climate measurements, very few studies have been carried out to estimate AET using the satellite-based PM approach. Therefore, the present study proposes to fill this gap in literature by applying the methodology proposed by [11] to a location in the humid tropics and verifying the accuracy of AET estimates with flux tower measurements.

\section{STUDY AREA}

Latent heat flux measurements required to validate the proposed AET estimation approach were obtained for the MaeKlong Watershed Research Station, Kanchanaburi located in Thailand. The flux tower at this location is part of the Asia Flux network (asiaflux.net) of towers installed to measure exchanges of carbon dioxide, water vapour and energy in Asia. Latent heat flux is measured using the eddy covariance technique. Instruments on the flux tower at the station are mounted at a height of $42 \mathrm{~m}$. Net radiation is measured using a radiometer, while air temperature is measured using a platinum resistance thermo-meter and water vapour with a capacitive hygrometer. All sensors are logged at sampling frequency of $4 \mathrm{~Hz}$, and fluxes are calculated using half-hourly averaging time. Asia flux database provides measured data for the years 2003 and 2004 for this flux tower. An area of $5 \mathrm{~km}$ $\times 5 \mathrm{~km}$ surrounding the flux tower was considered, which lies between $14^{\circ} 33^{\prime} 14^{\prime \prime}$ and $14^{\circ} 36^{\prime} 02^{\prime \prime}$ North latitudes and $98^{\circ} 49^{\prime} 29^{\prime \prime}$ and $98^{\circ} 52^{\prime 2} 28^{\prime \prime}$ East longitudes, with an average elevation of $231 \mathrm{~m}$. The region is covered by tropical seasonal deciduous forest with average canopy height of $30 \mathrm{~m}$. The dominant plant species found here are Shorea siamensis, vitex peduncularis and Xylia xylocarpa, and the soil type is Kandiustalfs (US soil taxonomy). The climate of the region 
according to Koppen's classification is tropical monsoon. This region experiences mean annual air temperature of $25^{\circ} \mathrm{C}$ and mean annual precipitation of $1500 \mathrm{~mm}$.

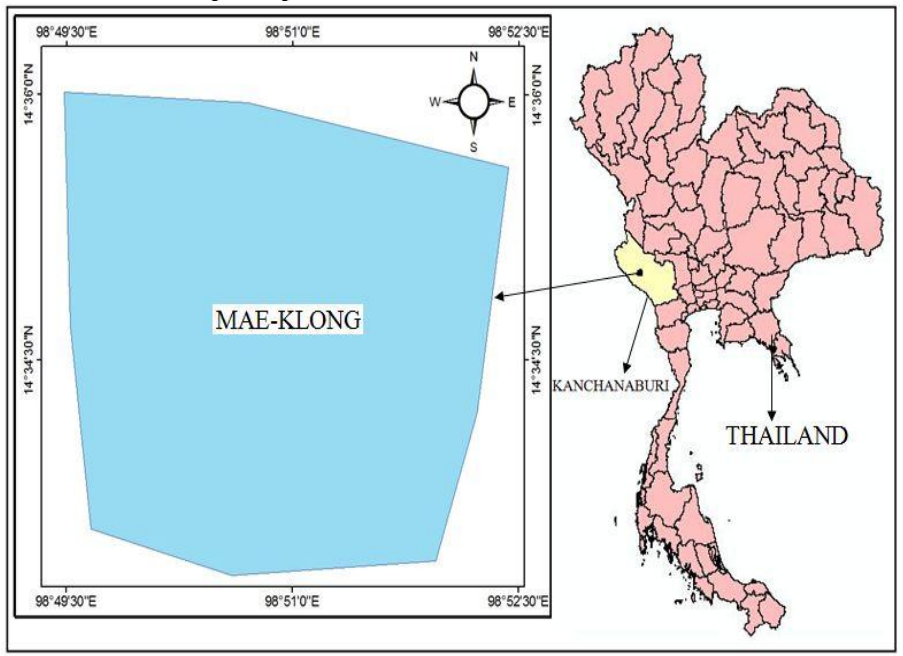

Fig. 1. Geographic location of the Mae-Klong region.

\section{DATA PRODUCTS}

Satellite images obtained from MODIS sensor mounted on Terra platform were used. MOD11A1 product of LST at 1000 $\mathrm{m}$ resolution, MOD09GA product of LSR at $1000 \mathrm{~m}$ resolution, MOD15A2 product of LAI is composited every eight days at $1000 \mathrm{~m}$ resolution and ASTGTM product of digital elevation model (DEM) at $30 \mathrm{~m}$ resolution for the Mae-Klong region are used in the analysis. Images corresponding to the study area for the years 2003 and 2004 during which the flux tower was operational were subject to search and only images free from cloud contamination were used. Accordingly, four dates in summer and four dates in winter of 2004 were selected to evaluate differences in latent heat flux $(\lambda \mathrm{ET})$ as influenced by season. Eight images of the year 2004 for Julian days 65, 81, 89 and 97 in summer and Julian days 329, 337, 345 and 353 in winter. Measured values of $\lambda \mathrm{ET}$ corresponding to the time of satellite overpass (11.15 hr) were used in comparison with those estimated by the proposed PM algorithm for the location of the flux tower. However, for Julian days 337 and 353, flux values recorded at $13.15 \mathrm{hr}$ and $12.15 \mathrm{hr}$ were used respectively since the $\lambda \mathrm{ET}$ values at $11.15 \mathrm{hr}$ was unavailable. Preliminary processing of MODIS images was performed using MODIS reprojection tool (MRT) so that all data products are cloud free and converted to standard format that can be read by MATLAB while processing. The tool also permits georeferencing and subsetting corresponding to the study area.

\section{METHODOLOGY}

A. AET Estimation using Penman-Monteith (PM) approach Latent heat flux ( $\lambda E T)$ may be estimated using the following form of the PM equation:

$$
\lambda \mathrm{ET}=\frac{[\Delta(\mathrm{Rn}-\mathrm{G})]+\rho_{\mathrm{a}} \mathrm{c}_{\mathrm{p}}\left(\frac{\mathrm{e}_{\mathrm{s}}-\mathrm{e}_{\mathrm{a}}}{\mathrm{r}_{\mathrm{a}}}\right)}{\Delta+\gamma\left[1+\frac{\mathrm{r}_{\mathrm{s}}}{\mathrm{r}_{\mathrm{a}}}\right]}
$$

where $\lambda$ ET $=$ latent heat flux $\left(\mathrm{W} / \mathrm{m}^{2}\right), \mathrm{r}_{\mathrm{s}}$ and $\mathrm{r}_{\mathrm{a}}=$ (bulk) surface and aerodynamic resistances $(\mathrm{s} / \mathrm{m}), \mathrm{Rn}=$ net surface radiation $\left(\mathrm{W} / \mathrm{m}^{2}\right), \mathrm{G}=$ Soil heat flux $\left(\mathrm{W} / \mathrm{m}^{2}\right), \Delta=$ slope of saturation vapour pressure versus air temperature curve $\left(\mathrm{kPa} /{ }^{\circ} \mathrm{C}\right), \gamma=$ Psychrometric constant $\left(\mathrm{kPa} /{ }^{\circ} \mathrm{C}\right), \mathrm{e}_{\mathrm{s}}$ and $\mathrm{e}_{\mathrm{a}}=$ Saturation vapor pressure $(\mathrm{kPa})$ and vapor pressure of air $(\mathrm{kPa})$, $\rho_{\mathrm{a}}=$ mean air density at constant pressure $(\mathrm{g} / \mathrm{m} 3)$ and $\mathrm{c}_{\mathrm{p}}=$ specific heat of the air $(\mathrm{J} / \mathrm{kg} / \mathrm{K})$.

\section{B. Surface conductance model}

Surface resistance $\left(r_{s}\right)$ for each pixel was estimated as the inverse of surface conductance (Gs) using the formulation proposed by Leuning et al [24],

$$
\begin{aligned}
& \mathrm{Gs}=\mathrm{Gc}\left[\frac{1+\frac{T \mathrm{Ga}}{(\varepsilon+1) \mathrm{Gc}}\left[\mathrm{f}-\frac{(\varepsilon+1)(1-\mathrm{f}) \mathrm{Gc}}{\mathrm{Ga}}\right]+\frac{\mathrm{Ga}}{\varepsilon \mathrm{Gi}}}{1-\mathrm{T}\left[\mathrm{f}-\frac{(\varepsilon+1)(1-\mathrm{f}) \mathrm{Gc}}{\mathrm{Ga}}\right]+\frac{\mathrm{Ga}}{\varepsilon \mathrm{Gi}}}\right] \\
& \mathrm{Gc}=\frac{\mathrm{Gsx}}{\mathrm{kQ}} \ln \left[\frac{\mathrm{Qh}+\mathrm{Q} 50}{\mathrm{Qh} \exp (-\mathrm{kQLAI}+\mathrm{Q} 50}\right]\left[\frac{1}{1+\frac{\mathrm{D}}{\mathrm{D} 50}}\right]
\end{aligned}
$$

where emissivity $(\varepsilon)=\Delta / \gamma, \mathrm{Gi}=\gamma\left(\mathrm{Rn}_{-} \mathrm{G}\right) /\left(\rho_{\mathrm{a}} \mathrm{c}_{\mathrm{p}} \mathrm{D}\right)$ is the iso-thermal conductance $(\mathrm{m} / \mathrm{s})$ Monteith and Unsworth [27], $\mathrm{Gc}=$ canopy conductance $(\mathrm{m} / \mathrm{s})$, Gs $=$ surface conductance $(\mathrm{m} / \mathrm{s}), T=\exp (-\mathrm{kALAI})$ is the fraction of total available energy absorbed by the soil surface, Gsx = maximum stomatal conductance $(\mathrm{m} / \mathrm{s}), \mathrm{kQ}=$ extinction coefficient for photosynthetically active radiation, $\mathrm{kA}=$ attenuation of net all-wave irradiance, $\mathrm{Qh}=$ photosynthetically active radiation at the top of canopy $(\mathrm{MJ} / \mathrm{m} 2 / \mathrm{d}), \mathrm{Q} 50=$ value of absorbed photosynthetic active radiation when $\mathrm{g}_{\mathrm{s}}=\mathrm{Gsx} / 2(\mathrm{MJ} / \mathrm{m} 2 / \mathrm{d}), \mathrm{D}$ $=$ vapour pressure deficit of air $(\mathrm{kPa}), \mathrm{D} 50=$ value of $\mathrm{D}$ when $\mathrm{g}_{\mathrm{s}}$ $=\mathrm{Gsx} / 2(\mathrm{kPa})$, and $\mathrm{f}$ is the fraction of equilibrium evaporation at soil surface (varying between 0 and 1 ).

\section{Actual Evapotranspiration (AET) estimation}

The ratio of latent energy to the available energy $(\mathrm{Rn}-\mathrm{G})$ is defined as the evaporative fraction (EF), which may be obtained from Equation (1) as:

$\mathrm{EF}=\frac{\lambda \mathrm{ET}}{\mathrm{R}_{\mathrm{n}}-\mathrm{G}}$

The actual 24 hour AET can be estimated from the instantaneous evaporative fraction $\mathrm{EF}$, and the daily averaged net radiation $\mathrm{Rn}_{\text {daily }}$ (Morse et al., 2000). 


$$
E_{\text {daily }}=\frac{8.64 \times 10^{\top} \times E F\left(R n_{\text {daily }}-G_{\text {daily }}\right)}{\lambda P_{w}}
$$

Where, $\lambda=$ Latent heat of water $\left(2.47 \times 10^{6} \mathrm{~kJ} / \mathrm{kg}\right)$ and $\rho_{\mathrm{w}}=$ Density of water $\left(1000 \mathrm{~kg} / \mathrm{m}^{3}\right)$

\section{Estimation of variables in PM equation}

Values of $\mathrm{e}_{\mathrm{s}}, \mathrm{e}_{\mathrm{a}}, \mathrm{c}_{\mathrm{p}}$ and $\rho_{\mathrm{a}}$ were calculated as per [2] and $\mathrm{r}_{\mathrm{a}}$ and $r_{s}$ was estimated by combining the procedures given in [11]. $R_{n}$ was computed by combining procedures described by [19] [2][6]. G in Equation (1) was estimated using a function proposed by Bastiaanssen [5]. $\Delta$ was calculated as per [18]. Pixel-wise fraction of vegetation (FV) values are estimated from MODIS land surface reflectance (LSR) product using the formula proposed by [7]. Albedo was calculated using the [7] model. The terms $\Delta, \mathrm{e}_{\mathrm{s}}, \mathrm{e}_{\mathrm{a}}, \rho_{\mathrm{a}}, \mathrm{r}_{\mathrm{a}}$ and $\gamma$ in Eq. (1) are calculated from the meteorological data of incoming solar radiation, temperature, humidity and wind speed [8].

\section{E. Estimation of variables in surface conductance model}

The following four parameters were set to constant values according to [11]: $\mathrm{kA}=\mathrm{kQ}=0.6, \mathrm{Q} 50=30 \mathrm{~W} / \mathrm{m}^{2}$ and D50 $=0.7 \mathrm{kPa}$. Qh is assumed to be correlated with incoming solar radiation (Rs) which is estimated by MODIS LSR data hence taken as $\mathrm{Qh}=0.45 \mathrm{Rs}$. $\mathrm{f}$ is assumed as (1-FV). Gsx was to be optimized but due to data scarcity the PM algorithm is been run for the values ranging from $0.006-0.009 \mathrm{~m} / \mathrm{s}$. The output is been validated with the flux data for eight days. For Gsx = $0.008 \mathrm{~m} / \mathrm{s}$ the PM algorithm yielded reasonably good correlation coefficient (R) and lowest Root Mean Squared Error (RMSE).

Estimation of $\lambda E T$ for each of the 27 pixels in the identified area using the algorithm for each date of acquired MODIS images was carried out using MATLAB software. ARC-View 9.3 software was used for pre-processing inputs and post-processing of results. PM algorithm used input data of MODIS land surface temperatures, leaf area index and surface reflectances. Other climatic data inputs were obtained from the Flux station.

\section{RESULTS AND DISCUSSIONS}

For the year 2004, four dates corresponding to the summer season (pre-monsoon) and four dates corresponding to the winter season (post-monsoon) were selected to evaluate differences in $\lambda \mathrm{ET}$ as influenced by season. Fig. 2 shows the estimated versus measured $\lambda \mathrm{ET}$ values for the Mae-Klong region. Estimated and measured values of $\lambda E T$ over the eight dates yielded values of $R$ of 0.94 , RMSE of $16.10 \mathrm{~W} / \mathrm{m}^{2}$. From the Fig. 2 it can be seen that the comparison between estimated and measured fluxes is good. These performance statistics for the PM based $\lambda E T$ algorithm are extremely encouraging and warrant further testing at other humid tropical locations.

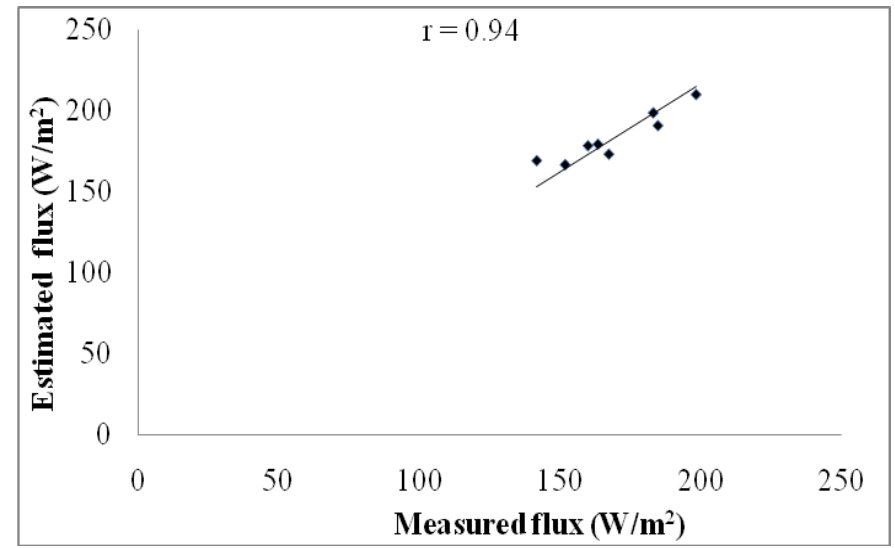

Fig. 2. Comparison of estimated and measured latent heat fluxes for selected eight dates using PM approach.

\section{CONCLUSIONS}

The present study was taken up mainly to test a satellite-based PM algorithm for estimation of AET (or $\lambda \mathrm{ET}$ ) proposed by [11]. For the purpose of validation of algorithm, it is been applied in humid tropical region using MODIS satellite data products as inputs. The AET model is developed in a way that it can also be used in data scare conditions by using only global datasets. The developed algorithm methodology in this study used of MODIS products like LST in place of ground-based air temperature, use of FV in place of NDVI and assumption of a fraction of energy available at the soil as (1-FV). Pixel-wise estimation of $\lambda$ ET by using PM algorithm was been validated by applying it in the humid tropical Mae-Klong region, Thailand where flux tower data was available. Comparison of estimated and measured fluxes on eight days in 2004 yielded R of 0.94 and RMSE of $16.10 \mathrm{~W} / \mathrm{m}^{2}$. The methodology incorporated in the algorithm yielded reasonably good $\lambda$ ET estimates at this humid tropical location. Hence, the methodology will prove helpful in regional scale monitoring and mapping of AET in humid tropical regions in a convenient and cost effective-manner.

\section{ACKNOWLEDGMENT}

The authors thank Dr. Takahisa Maeda, AIST, Japan for providing flux tower data for Mae-Klong region, Thailand, and for granting permission to publish this article.

\section{REFERENCES}

[1] Allen RG, Pereira LS, Howell TA, Jensen ME. Evapotranspiration information reporting: I. Factors governing measurement accuracy. Agricultural Water Management. 2011 Apr 30; 98 (6):899-920. http://dx.doi.org/10.1016/j.agwat.2010.12.015

[2] Allen RG, Pereira LS, Raes D, Smith M. Crop evapotranspiration-Guidelines for computing crop water requirements-FAO Irrigation and drainage paper 56. FAO, Rome. 1998;300(9):D05109.

[3] Anderson MC, Kustas WP, Norman JM, Hain CR, Mecikalski JR, Schultz L, González-Dugo MP, Cammalleri C, d'Urso G, Pimstein A, Gao F. Mapping daily evapotranspiration at field to continental scales using geostationary and polar orbiting satellite imagery. Hydrology and Earth System Sciences. 2011 Jan 21;15(1):223-39. http://dx.doi.org/10.5194/hess-15-223-2011

[4] Bastiaanssen WG, Noordman EJ, Pelgrum H, Davids G, Thoreson BP, Allen RG. SEBAL model with remotely sensed data to improve water-resources management under actual field conditions. Journal of irrigation and drainage engineering. 2005 Feb 1. 
http://dx.doi.org/10.1061/(ASCE)0733-9437(2005)131:1(85)

[5] Bastiaanssen WG. SEBAL-based sensible and latent heat fluxes in the irrigated Gediz Basin, Turkey. Journal of hydrology. 2000 Mar 27;229(1):87-100. http://dx.doi.org/10.1016/S0022-1694(99)00202-4

[6] Bastiaanssen WG. Regionalization of surface flux desities and moisture indicators in composite terrain: a remote sensing approach under clear skies in Mediterranean climates. Landbouw universiteit te Wageningen; 1995 Nov 17.

[7] Carlson TN, Ripley DA. On the relation between NDVI, fractional vegetation cover, and leaf area index. Remote sensing of Environment. 1997 Dec 31;62(3):241-52. http://dx.doi.org/10.1016/S0034-4257(97)00104-1

[8] Cleugh HA, Leuning R, Mu Q, Running SW. Regional evaporation estimates from flux tower and MODIS satellite data. Remote Sensing of Environment. 2007 Feb 15;106(3):285-304. http://dx.doi.org/10.1016/j.rse.2006.07.007

[9] Guerschman JP, Van Dijk AI, Mattersdorf G, Beringer J, Hutley LB, Leuning R, Pipunic RC, Sherman BS. Scaling of potential evapotranspiration with MODIS data reproduces flux observations and catchment water balance observations across Australia. Journal of Hydrology. 2009 May 5;369(1):107-19. http://dx.doi.org/10.1016/j.jhydrol.2009.02.013

[10] Huete A, Didan K, Miura T, Rodriguez EP, Gao X, Ferreira LG. Overview of the radiometric and biophysical performance of the MODIS vegetation indices. Remote sensing of environment. 2002 Nov 30;83(1):195-213. http://dx.doi.org/10.1016/S0034-4257(02)00096-2

[11] Leuning R, Zhang YQ, Rajaud A, Cleugh H, Tu K. A simple surface conductance model to estimate regional evaporation using MODIS leaf area index and the Penman-Monteith equation. Water Resources Research. 2008 Oct $1 ; 44(10)$ http://dx.doi.org/10.1029/2007WR006562

[12] Liang S. Narrowband to broadband conversions of land surface albedo I: Algorithms. Remote Sensing of Environment. 2001 May 31;76(2):213-38. http://dx.doi.org/10.1016/S0034-4257(00)00205-4

[13] Los SO, Pollack NH, Parris MT, Collatz GJ, Tucker CJ, Sellers PJ, Malmström CM, DeFries RS, Bounoua L, Dazlich DA. A global 9-yr biophysical land surface dataset from NOAA AVHRR data. Journal of Hydrometeorology. $2000 \mathrm{Apr} ; 1(2): 183-99$. http://dx.doi.org/10.1175/1525-7541(2000)001<0183:AGYBLS>2.0.CO; 2

[14] Morse A, Tasumi M, Allen RG, Kramber WJ. Application of the SEBAL methodology for estimating consumptive use of water and streamflow depletion in the Bear River Basin of Idaho through remote sensing. Idaho Department of Water Resources-University of Idaho. 2000 Dec 15.

[15] Mu Q, Zhao M, Running SW. Improvements to a MODIS global terrestrial evapotranspiration algorithm. Remote Sensing of Environment. 2011 Aug $15 ; 115(8): 1781-800$ http://dx.doi.org/10.1016/j.rse.2011.02.019

[16] Mu Q, Heinsch FA, Zhao M, Running SW. Development of a global evapotranspiration algorithm based on MODIS and global meteorology data. Remote Sensing of Environment. 2007 Dec 28;111(4):519-36. http://dx.doi.org/10.1016/j.rse.2007.04.015

[17] Myneni RB, Hoffman S, Knyazikhin Y, Privette JL, Glassy J, Tian Y, Wang Y, Song X, Zhang Y, Smith GR, Lotsch A. Global products of vegetation leaf area and fraction absorbed PAR from year one of MODIS data. Remote sensing of environment. 2002 Nov 30;83(1):214-31. http://dx.doi.org/10.1016/S0034-4257(02)00074-3

[18] Richards JM. A simple expression for the saturation vapour pressure of water in the range- 50 to $140^{\circ}$ C. Journal of Physics D: Applied Physics. 1971 Apr 1;4(4):L15. http://dx.doi.org/10.1088/0022-3727/4/4/101

[19] Tasumi M, Trezza R, Allen RG, Wright JL. US Validation tests on the SEBAL model for evapotranspiration via satellite. In Proceedings of 54th IEC Meeting of the International Commission on Irrigation and Drainage (ICID) Workshop remote sensing of ET for large regions 2003 Sep 17 (Vol. 17).

[20] Vinukollu RK, Wood EF, Ferguson CR, Fisher JB. Global estimates of evapotranspiration for climate studies using multi-sensor remote sensing data: Evaluation of three process-based approaches. Remote Sensing of Environment. 2011 Mar 15;115(3):801-23 http://dx.doi.org/10.1016/j.rse.2010.11.006

[21] Wan Z, Zhang Y, Zhang Q, Li ZL. Validation of the land-surface temperature products retrieved from Terra Moderate Resolution Imaging
Spectroradiometer data. Remote sensing of Environment. 2002 Nov 30;83(1):163-80.

http://dx.doi.org/10.1016/S0034-4257(02)00093-7 